\title{
(息)
}

Citation:

Carless, D and Douglas, K (2017) Narrative research. The Journal of Positive Psychology: dedicated to furthering research and promoting good practice, 12 (3). pp. 307-308. ISSN 1743-9779 DOI: https://doi.org/10.1080/17439760.2016.1262611

Link to Leeds Beckett Repository record:

https://eprints.leedsbeckett.ac.uk/id/eprint/2028/

Document Version:

Article (Accepted Version)

Date of Acceptance: 12 Sep 2015

The aim of the Leeds Beckett Repository is to provide open access to our research, as required by funder policies and permitted by publishers and copyright law.

The Leeds Beckett repository holds a wide range of publications, each of which has been checked for copyright and the relevant embargo period has been applied by the Research Services team.

We operate on a standard take-down policy. If you are the author or publisher of an output and you would like it removed from the repository, please contact us and we will investigate on a case-by-case basis.

Each thesis in the repository has been cleared where necessary by the author for third party copyright. If you would like a thesis to be removed from the repository or believe there is an issue with copyright, please contact us on openaccess@leedsbeckett.ac.uk and we will investigate on a case-by-case basis. 


\section{Narrative Research}

\section{David Carless and Kitrina Douglas \\ (Leeds Beckett University)}

Forthcoming in Journal of Positive Psychology

Narrative is both a research method and a way of theorising psychological and social phenomena. Although the term narrative has become prominent in the last decade or two, its roots stretch back through biographical and life history approaches. Narrative methodologies have informed much of our research over the past 15 years, which has explored mental health and identity development in sport and physical activity contexts (for examples, see Carless \& Douglas, 2010a; Douglas \& Carless, 2015). Based on this work, we wish to propose six qualities of narrative research that have much to offer positive psychology researchers.

First, narrative offers rich insights into lived experience. Rather than focusing on constructs, opinions or abstractions, narrative methods prioritise an individual's experience of concrete events. Rather then 'hovering over the surface' of life, keeping lived experience at arms-length, narrative accounts embrace the particularity and complexity of individual's lived experience (e.g., Carless et al., 2014). Recounting moments of personal experience in story form (detailing what happened, where, when, to whom, what were the consequences) is important not so much to reveal the objective details of events but to understand the individual's subjective responses to those events.

Second, narrative approaches shed light on the meaning of personal experience. As others have observed (e.g., McAdams, 1993), telling stories about the events of one's life is a primary way through which meaning is created and communicated. Working narratively allows researchers to learn from each participant's position as expert on her/his own life, understanding and co-constructing meaning through a reciprocal, dialogical interaction. For example, the varied meanings of life in elite sport are evident in our research with professional golfers (e.g., Douglas \& Carless, 2009a, 2012a, 2015). Within a trusting researcher-participant relationship, individuals shared personal stories that challenge the widely held (i.e., dominant) assumption that elite sport is all about performance outcomes. Women's discovery and relational stories broaden life possibilities for athletes and show how 
success at the elite level can be achieved while valuing exploration over sacrifice, play over work, caring relationships over self-focus, and sensitivity over mental toughness.

Third, narrative offers insights into the trajectory of life across time. Rather than providing a static 'snapshot' of a life at a fixed moment in time, narrative methods offer something akin to a 'movie' that follows a significant portion of the storyteller's lifespan (e.g., Douglas \& Carless, 2009a, 2009b). This permits consideration of development over time, revealing the consequences of events that might otherwise appear unimportant. For example, our work with military personnel who have experienced physical and/or psychological trauma (e.g., Carless, 2014) illustrates how soldier's life stories changed over time in response to adverse life circumstances and, later, new opportunities that, as one participant put it, 'opened some doorways in my head'. This study has direct links to positive psychology as it reveals how stories of loss and isolation were transformed towards more hopeful, connected, forward-looking stories.

Fourth, narrative permits a focus on both the personal and the social. Although stories prioritise personal experience, they also reveal sociocultural context because an individual's story is shaped by the dominant narrative/s within their culture (McLeod, 1997). Narrative methods thereby reveal how psychological processes are influenced by the sociocultural structures within which they unfold (e.g., Carless \& Douglas, 2013). By attending to the interplay of structure and agency, we learn how individuals negotiate their identity, morality and behaviour within their particular life context.

Fifth, narrative offers insights into what life is like as an embodied - living, breathing, feeling - human being. Storytelling is an embodied act that draws on one's experience of the world through one's body. Thus, narrative studies reveal how bodies and stories impact, shape and constitute each other (e.g., Carless, 2010). These insights may challenge reductionist and mechanistic portrayals of human beings by providing holistic and emotionally rich perspectives. Using narrative forms (such as stories) to represent research allows participants' embodied presence and emotional richness to be preserved, engaging diverse audiences (e.g., Carless \& Douglas, 2010b; Douglas \& Carless, 2008, 2009b).

Sixth, narrative research calls for ethical relational engagement. Because "stories as acts of telling are relationships" (Frank, 2000, p. 354), good narrative research requires an open, accepting, empathetic and trusting relationship between researcher and participant. This kind of relationship can usually be built only through relational engagement over time, when participants feel safe to express emotions and vulnerabilities that otherwise remain hidden (e.g., Douglas \& Carless, 2009b, 2012b). The open interview approaches used in much 
narrative research allow participants the freedom to raise issues that are meaningful to them. Sharing marginal, taboo or silenced stories often challenges existing understandings and theories. When we take these stories seriously, it may become apparent that it is $u s$ - the socalled 'experts' - who need to change, as our horizon of interest opens and our understanding of the many ways of being human deepens. 


\section{References}

Carless, D. (2010). Who the hell was that? Stories, bodies and actions in the world. Qualitative Research in Psychology, 7(4), 332-344.

Carless, D. (2014). Narrative transformation among military personnel on an adventurous training and sport course. Qualitative Health Research, 24(10), 1440-1450.

Carless, D., \& Douglas, K. (2010a). Sport and physical activity for mental health. Oxford: Wiley-Blackwell.

Carless, D., \& Douglas, K. (2010b). Performance ethnography as an approach to healthrelated education. Educational Action Research, 18(3), 373-388.

Carless, D., \& Douglas, K. (2013). Living, resisting, and playing the part of athlete: Narrative tensions in elite sport. Psychology of Sport and Exercise, 14(5), 701-708.

Carless, D., Sparkes, A., Douglas, K., \& Cooke, C. (2014). Disability, inclusive adventurous training and adapted sport: Two soldiers' stories of involvement. Psychology of Sport and Exercise, 15(1), 124-131.

Douglas, K. \& Carless, D. (2008). Using stories in coach education. International Journal of Sports Science and Coaching, 3(1), 33-49.

Douglas, K., \& Carless, D. (2009a). Abandoning the performance narrative: Two women's stories of transition from professional golf. Journal of Applied Sport Psychology, 21(2), 213230 .

Douglas, K., \& Carless, D. (2009b). Exploring taboo issues in professional sport through a fictional approach. Reflective Practice, 10(3), 311-323.

Douglas, K., \& Carless, D. (2012a). Membership, golf and a story about Anna and me: Reflections on research in elite sport. Qualitative Methods in Psychology Bulletin, 13, 27-35.

Douglas, K., \& Carless, D. (2012b). Taboo tales in elite sport: Relationships, ethics, and witnessing. Psychology of Women Section Review, 14(2), 50-56.

Douglas, K., \& Carless, D. (2015). Life story research in sport: Understanding the experiences of elite and professional athletes through narrative. Abingdon: Routledge.

Frank, A.W. (2000). The standpoint of storyteller. Qualitative Health Research, 10(3), 354365.

McAdams, D. (1993). The stories we live by. New York, NY: The Guildford Press.

McLeod, J. (1997). Narrative and psychotherapy. London: Sage. 